\title{
Follicolous fungi occurring at Biratnagar, Nepal
}

\author{
I.M. Bhagat \\ Department of Botany \\ Post Graduate Campus, Tribhuvan University, Biratnagar, Nepal \\ E-mail: drimbhagat@yahoo.com
}

Key words: Foliicolous fungi, vegetables, Biratnagar

There are different types of vegetables cultivated in different seasons. Vegetables are attacked by different types of pathogens such as fungi, viruses, nematodes and bacteria. Out of all these pathogens the fungi play an important role in mass destruction of vegetables. They reduce the quality and quantity of vegetable production. There are different kinds of diseases caused by fungi in vegetables and most commonly they are found to attack the leaves of the plants.

The fungi attacking the leaves of the plants are called the 'foliicolous fungi'. There are many foliicolous fungi which produce different types of symptoms. There is considerable reduction in the photosynthetic area of the plant when fungi start to infect the leaf. Sometimes complete defoliation also occurs by these types of infection and the productivity of host plant substantially reduces. Thus foliicolous fungi are of great concern. The present paper provides detail information about the foliicolous fungi of Biratnagar particularly occurring on the vegetables.

Biratnagar is situated at $26^{\circ} 20^{\prime} \mathrm{N}$ latitude and $87^{\circ} 16^{\prime} \mathrm{E}$ longitude and altitude $72 \mathrm{~m}$ above sea level. Biratnagar is surrounded by Singhia river in the east, Kesalia river in the west, Tanki Sinwari Dhat in the north and Jogbani (India) in the south. The soil is a part of alluvial Gangetic plain of northern Indian sub-continent. About 59\% of the areas are being utilized for agriculture, $25 \%$ for residences, $4 \%$ for commercial and 3\% for industrial purpose (Subedi, 1997).

The collections of foliicolous fungi on vegetables were taken from different vegetable cultivating localities of Biratnagar like P.G. Campus, Biratnagar, Barganchhi, Abhibadantole, Tintolia, Mills area and most of the kitchen gardens of houses from these areas. The diseased parts of the leaves were examined and the specimens were collected in polythene bags. The collected specimens were identified with the help of available literature (Barnett, 1965; Mehrotra, 1969; Budhathoki, 1988; Rangaswami, 1996). The places and dates of collection were noted in the field diary.

From the collected specimens, the infected tissues were separated by cutting or by teasing and slides were prepared in lacto phenol for permanency. The slides were made semi-permanent by coating them with nail polish and were preserved for further use. The prepared slides were critically studied with camera lucida for drawing morphological characters of the fungi. Spores and conidia were measured by the help of ocular and stage micrometer.

The vegetables collected during the survey were Solanum tuberosum, Brassica oleracea, Brassica campestris,,Solanum melongena, Lycopersicum esculentum, Cucurbita pepo, Cucurbita maxima, , Raphanus sativus, Momordica charantia, Coccinea cordifolia, Amaranthus spinosa, Hibiscus esculentus, Capsicum annum, Vicia faba, Colocasia esculenta. The fungi collected were Alternaria sp., Cercospora sp., Uromyces sp., Albugo sp., Phythopthora sp.. Erysiphe sp. and Peronospora sp. 
Table 1. List of foliicolous fungi and its hosts at Biratnagar.

\begin{tabular}{|c|c|c|c|}
\hline S.N Vegetable & Pathogen & Disease name & Family name \\
\hline 1. Amaranthus spinosa & Albugo sp. & White rust & Albuginaceae \\
\hline Brassica campestris & Alternaria brassicae & Early blight & Dematiaceae \\
\hline B.nigra & Alternaria sp. & Early blight & Dematiaceae \\
\hline B.oleracea & Alternaria sp. & Early blight & Dematiceae \\
\hline B.oleracea & Peronospora sp. & Downy mildew & Poronosporaceae \\
\hline B.raphanus & Alternaria sp. & Early blight & Dematiaceae \\
\hline Capsicum anum & Cercospora sp. & Leaf spot & Dematiaceae \\
\hline Coccinia cordifolia & Erysiphe sp. & Powdery mildew & Erysiphaceae \\
\hline 9. Colocasia esculenta & Phytopthora sp. & Late blight & Phythiaceae \\
\hline 10. Cucurbita maxima & Erysiphe sp. & Powdery mildew & Erysiphaceae \\
\hline 11. С.реро & Erysiphe cichoracearum & Powdery mildew & Erysiphaceae \\
\hline 12 Hibiscus esculentus & Cercospora $\mathrm{sp}$ & Leaf spot & Dematiaceae \\
\hline 13. Lagenarai siceravia & Erysiphe sp. & Powdery mildew & Erysiphaceae \\
\hline 14. Lycopersicum esculentum & Alternaria sp. & Early blight & Dematiaceae \\
\hline 15. Momordica charantia & Cercospora sp. & Leaf spot & Dematiaceae \\
\hline 16. Raphanus sativum & Albugo sp. & White rust & Albuginaceae \\
\hline 17. Solanum melongena & Alternaria sp. & Early blight & Dematiaceae \\
\hline 18. S. melongena & Cercospora sp. & Leaf spot & Dematiaceae \\
\hline 19. S. tuberosum & Alternaria solani & Early blight of potato & Dematiaceae \\
\hline 20. S.tuberosum & Ptythopthora infestans. & Late blight & Phythiaceae \\
\hline 21. Vicia faba & Uromyces sp. & Rust & Pucciniaceae \\
\hline
\end{tabular}

Out of all collected fungi Alternaria sp. and Cercospora sp. were frequently found. Thus they were the most common pathogens found during summer season. Erysiphe sp. was found mostly from damp areas and Alternaria sp. from open field where the wind favours the dissemination of spores. Most of the fungi have been seen to have an epidemic effect on the plant covering almost all the nearby cultivated land e.g. Alternaria sp.

\section{References}

Barnett, H.L. 1965. llustrated Genera of Imperfect Fungi. Burgess Publishing Company. 426s SIXT. strect Minnepolis 15 Minn.

Budhathoki, U. 1988. Studies on foliicolous fungi from Kathmandu valley (Nepal). Ph.D. Thesis Deptment of Botany, University of Gorakhapur, India.

Mehrotra, R.S. 1969. Plant Pathology. Tata McGraw Hill Publishing Co. Ltd.

Rangaswami, G. 1996. Disease of Crop Plant in India. Printed-Hall of India Pvt. Ltd. New Delhi $\left(3^{\text {rd }}\right.$ edt $)$.

Subedi, D.R. 1997. Brief History of Biratnagar. Biratnagar Muncipality (2054 B.S.). 